Boise State University

ScholarWorks

6-1-2014

Factors Associated with Flammulated Owl and Northern Saw-Whet Owl Occupancy in Southern Idaho

Micah N. Scholer

Boise State University

Matthias Leu

College of William and Mary

James R. Belthoff

Boise State University 


\title{
FACTORS ASSOCIATED WITH FLAMMULATED OWL AND NORTHERN SAW-WHET OWL OCGUPANCY IN SOUTHERN IDAHO
}

\author{
MicAH N. SCHOLER ${ }^{1}$ \\ Department of Biological Sciences and Raptor Research Center, Boise State University, Boise, ID 83275 U.S.A.
}

\author{
MATTHIAS LEU \\ Biology Department and Institute for Integrative Bird Behavior Studies, College of William and Mary, \\ Williamsburg, VA 23187 U.S.A.
}

JAMES R. BELTHOFF

Department of Biological Sciences and Raptor Research Center, Boise State University, Boise, ID 83275 U.S.A

\begin{abstract}
Spatially explicit models depicting species occupancy offer a useful conservation tool for land managers. Using occurrence data collected in 2009 and 2010 from the Boise National Forest, Idaho, we developed distribution models for Flammulated Owls (Psiloscops flammeolus) and Northern Saw-whet Owls (Aegolius acadicus) to explore associations between habitat factors and owl occupancy. We then spatially applied these models in a Geographic Information System. We considered land cover and topographic variables at three spatial scales: $0.4-\mathrm{km}, 1-\mathrm{km}$, or 3-km-radius plots centered on point-count locations $(n=$ 150 ) with resolution of land covers at $30 \mathrm{~m}$. Flammulated Owls occupied 27 (18\%) point-count locations and occurred in areas with a higher proportion of Douglas-fir (Pseudotsuga menziesii) at the 0.4-km scale, less diverse land cover composition at the 1-km scale, and in south-facing aspects at the 3-km scale. Northern Saw-whet Owls occupied $45(30 \%)$ point-count locations and were associated with relatively flat terrain at the $0.4-\mathrm{km}$ scale that had larger proportions of non-forest land cover. At the $1-\mathrm{km}$ and $3-\mathrm{km}$ scales, Northern Saw-whet Owls occurred in areas with south-facing aspects having a higher proportion of ponderosa pine (Pinus ponderosa), respectively. Biologists and land managers interested in the conservation of Flammulated Owls and Northern Saw-whet Owls can use our approach to delineate habitats important for these owls or to help identify locations suitable for restoration.
\end{abstract}

Key Words: Flammulated Owl; Psiloscops flammeolus; Northern Saw-whet Owl; Aegolius acadicus; Idaho; occupancy; spatially explicit model.

\section{FACTORES ASOCIADOS CON LA OCUPACIÓN DE PSILOSCOPS FLAMMEOLUS Y AEGOLIUS ACADICUS EN EL SUR DE IDAHO}

\begin{abstract}
RESUMEN.-Los modelos espacialmente explícitos utilizados para describir la ocupación representan una herramienta útil de conservación para los encargados del manejo territorial. Desarrollamos modelos de distribución para Psiloscops flammeolus y Aegolius acadicus utilizando datos de ocurrencia registrados en 2009 y 2010 en el Parque Nacional Boise, Idaho, para explorar asociaciones entre las características del hábitat y la ocupación de las lechuzas. Luego aplicamos espacialmente estos modelos en un Sistema de Información Geográfica. Consideramos la cobertura del suelo y las variables topográficas a tres escalas espaciales: parcelas de radio de $0.4 \mathrm{~km}, 1 \mathrm{~km}$ o $3 \mathrm{~km}$ centradas en sitios de puntos de conteo $(n=150)$ con resolución de cobertura del suelo de $30 \mathrm{~m}$. P. flammeolus ocupó 27 (18\%) puntos de conteo y estuvo presente en áreas con una mayor proporción de Pseudotsuga menziesii a la escala de $0.4 \mathrm{~km}$. A. acadicus ocupó 45 (30\%) puntos de conteo y estuvo asociada a un terreno relativamente plano a la escala de $0.4 \mathrm{~km}$ con una mayor proporción de cobertura del suelo no boscosa. A las escalas de 1 y $3 \mathrm{~km}$, A. acadicus estuvo presente en áreas con laderas de exposición sur con una mayor proporción de Pinus ponderosa. Los biólogos y encargados del manejo territorial interesados en la conservación de $P$. flammeolus y A. acadicus pueden utilizar nuestro enfoque para determinar hábitats importantes para estas lechuzas o para ayudar a identificar áreas apropiadas para ser restauradas.
\end{abstract}

[Traducción del equipo editorial]

\footnotetext{
${ }^{1}$ Email address: micahscholer@gmail.com
} 
Relatively little is known about the distribution, abundance, and population trends of many forestdwelling owl species, partially because of their nocturnal habits, secretive behavior, and, in some cases, rarity (Johnson et al. 1981). In the forests of southern Idaho, silviculture practices, livestock grazing, fire suppression, recreation, and other human activities may negatively affect owl populations (Wisdom et al. 2000). Cavity-nesting owls may be particularly vulnerable to habitat perturbations because they rely on breeding cavities often associated with mature forest stands (McCallum 1994, Imbeau et al. 2001, Saab et al. 2007, Rasmussen et al. 2008). Effective management for cavity-nesting owls therefore necessitates understanding their resource requirements and patterns of occupancy across the landscape.

Landscape-scale habitat features often help drive ecological processes (Turner et al. 2001). Spatially explicit modeling of these relationships is useful for identifying habitat associations (Groce and Morrison 2010), highlighting suitable but unoccupied habitat (Russell et al. 2007), and predicting effects of habitat manipulations or restoration (Doherty et al. 2008, Grossman et al. 2008). Moreover, the scale at which species respond to factors in their environment may differ (Turner et al. 2001, Cushman and McGarigal 2002). Hence, knowledge of the scale at which habitat use occurs is valuable for species management (Doherty et al. 2008).

Our goals were to explore land cover and topographic factors associated with occupancy of Boreal Owls (Aegolius funereus), Flammulated Owls (Psiloscops flammeolus), and Northern Saw-whet Owls (hereafter saw-whet owl; A. acadicus) and use these to develop spatial predictions of their distributions within the Boise National Forest (BNF), Idaho. Understanding patterns of occupancy is important for conservation and management of owls, as Boreal Owls and Flammulated Owls are listed as species of special concern in Idaho, and no systematic surveys for saw-whet owls have been conducted in the BNF. These owl species generally occupy mature forests typified by the open physiognomy of ponderosa pine (Pinus ponderosa) and Douglas-fir (Pseudotsuga menziesii) at lower elevations $(<1500 \mathrm{~m})$, and mixed conifer forest at higher elevations (Hayward and Garton 1988, McCallum 1994, Rasmussen et al. 2008). Specifically, we aimed to: (1) document cavity-nesting owl distributions based on nocturnal broadcast surveys, (2) develop models of probability of occurrence for cavitynesting owls adjusted for imperfect detection, (3) estimate the most representative scale at which land cover or topographic characteristics were associated with occupancy of cavity-nesting owls, and (4) spatially depict owl occurrence.

\section{Study ARea}

Our study was conducted within and near the $10260-\mathrm{km}^{2}$ BNF, in southern Idaho (Fig. 1). The BNF comprised mainly mountainous terrain, with elevation ranging from 870-3250 masl. Forest cover was dominated by conifers, and deciduous trees made up $<1 \%$ of the total land cover. Douglas-fir and ponderosa pine predominated at lower to midelevations, whereas grand fir (Abies grandis) occurred at similar elevations but in smaller amounts and only in the northern portion of the study area (Steele et al. 1981). At higher elevations, subalpine fir (A. lasiocarpa), Engelmann spruce (Picea engelmannii), and lodgepole pine ( $P$. contorta) predominated. Shrubs such as ninebark (Physocarpus malvaceus), snowberry (Symphoricarpos spp.), serviceberry (Amelanchier alnifolia), rose (Rosa spp.), huckleberry (Vaccinium spp.), and chokecherry (Prunus virginiana) were common in forest understories. Snowbrush (Ceanothus velutinus), bitterbrush (Purshia tridentata), and sagebrush (Artemisia tridentata) inhabited drier, south-facing aspects (Steele et al. 1981). Deciduous tree and shrub species grew mainly in riparian areas and drainages and included aspen (Populus tremuloides), black cottonwood ( $P$. trichocarpa), willows (Salix spp.), dogwood (Cornus sericea), cascara (Rhamnus purshiana), and thimbleberry (Rubus parviflorus).

\section{Methods}

From February to May 2009 and 2010, we conducted point-count surveys for Boreal Owls, Flammulated Owls, and saw-whet owls using audio broadcasts of owl vocalizations (Johnson et al. 1981). We continued surveys for Flammulated Owls in June of both years because they are migratory and often do not arrive on the breeding grounds until May (McCallum 1994). Additionally, detectability of Flammulated Owls may be highest during June (Barnes and Belthoff 2008).

We used ArcGIS 9.3 (Environmental Systems Research Institute Inc., Redlands, California, U.S.A.) to help select point-count locations in appropriate forested habitat. Because we began surveys in winter, point-count locations had to be accessible by researchers on snowshoes, cross-country skis, or on foot. The point-count locations were therefore logistically constrained to U.S.D.A. Forest Service roads 


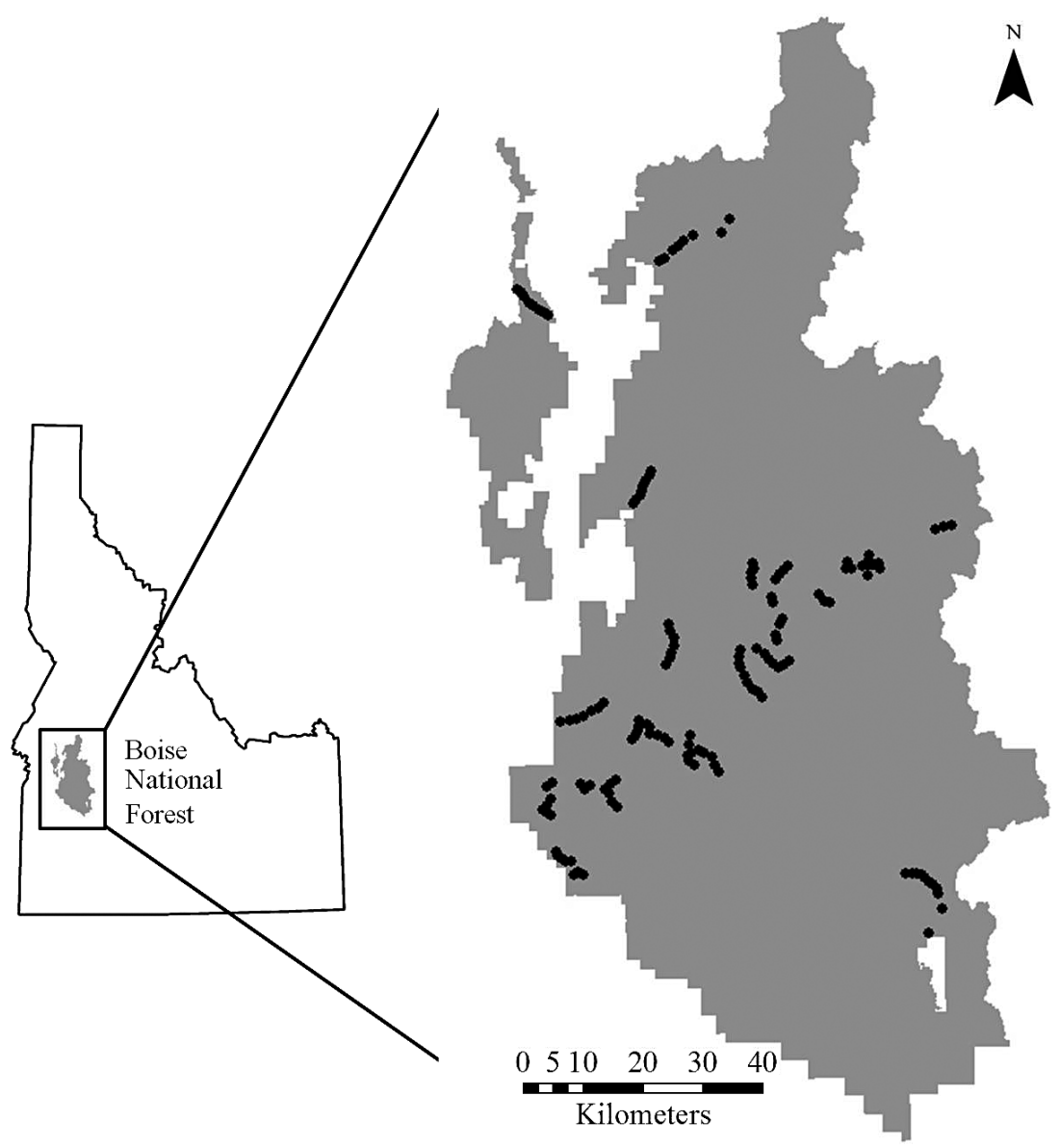

Figure 1. Map of the Boise National Forest in southwestern Idaho, U.S.A., and point-count locations surveyed for cavitynesting owls during February to June, 2009-2010.

and trails. We placed an initial point-count location near the beginning of an accessible road or trailhead and separated subsequent point-counts by $800-1500 \mathrm{~m}$. We randomly stratified point-count locations by forested land-cover classes and placed proportionately more in dominant classes such as Douglas-fir and ponderosa pine. To increase spatial coverage, we surveyed different points-count locations each year ( $n=82$ in 2009 and 68 in 2010).

Survey Protocol. Each point-count consisted of an initial 3-min listening period, followed by a series of broadcasts of Flammulated Owl and Boreal Owl vocalizations with audio output of 90-110 dB (Fuller and Mosher 1987) using a broadcast system (NX3 Fox Pro Wildlife Caller, FOXPRO Inc., Lewistown, Pennsylvania, U.S.A.). The recordings were of male vocalizations typically associated with territorial display (Stokes Field Guide to Bird Songs ${ }^{\circledR}$,
Time Warner Audio Books, New York, New York, U.S.A.). We broadcasted for the smaller Flammulated Owls first, to reduce possible intimidation by larger owl species (Hayward and Garton 1988). We recorded saw-whet owls based on their response to other species' calls (Kissling et al. 2010). In particular, saw-whet owls respond similarly to vocalizations of conspecifics and Boreal Owls (Francis and Bradstreet 1997). We broadcast recordings of individual owl vocalizations for $30 \mathrm{sec}$ followed by $1 \mathrm{~min}$ of listening and repeated this twice for each species in the protocol while rotating the Wildlife Caller through $360^{\circ}$. In total, individual point-counts took 9 min to complete and were conducted between 30 min after sunset and 03:00 $\mathrm{H}$.

We visited each point-count location (1) three times during February-May to survey Flammulated, Boreal, and saw-whet owls, and (2) one to three 
additional times in June to continue surveys for Flammulated Owls. Repeat visits to point-count locations were separated by at least $7 \mathrm{~d}(\bar{x}=14.7 \mathrm{~d}$ between visits). Repeat visits allowed us to develop a detection history of each species at each point-count location for use in occupancy modeling of owls (MacKenzie et al. 2002, Bailey et al. 2009, Yakulic et al. in press).

Temporal and Environmental Detection Variables. During each point-count we recorded two temporal and six environmental variables that potentially influenced owl detectability. Temporal variables were Julian date and time (hr) after sunset. We recorded the environmental variables temperature $\left({ }^{\circ} \mathrm{C}\right)$, barometric pressure (psi), relative humidity $(\%)$, and average wind speed $\left(\mathrm{km} \mathrm{hr}^{-1}\right)$ using a Kestrel 3500 Weather Meter (Forestry Supply, Inc., Jackson, Missouri, U.S.A.) and visually estimated percent cloud cover (0-100). Following Kissling et al. (2010) we indexed ambient noise levels as 1 (quiet), 2 (some intermittent, but not distracting noise), 3 (moderate noise that could reduce owl detectability), and 4 (constant noise). We used the resulting detection history generated from multiple visits to each point-count location along with temporal and environmental variables from each visit to adjust occupancy estimates for imperfect detection for each owl species. We detected no Boreal Owls, so our analyses of owl occupancy and detectability considered only Flammulated Owls and saw-whet owls.

Scale, Land Cover, and Topographic Variables. We used ArcMap 9.3 to characterize land-cover composition and topographic features at three different scales: $0.4-\mathrm{km}($ area $=50 \mathrm{ha}), 1-\mathrm{km}($ area $=314 \mathrm{ha})$, and 3-km-radius (area $=2826 \mathrm{ha}$ ) circular plots centered on each point-count location. We used the $0.4-\mathrm{km}$ buffer distance to represent features that Flammulated Owls (McCallum 1994, Barnes 2007) and saw-whet owls (Hayward and Garton 1988, Rasmussen et al. 2008) may experience within their approximate home-range sizes. We used the $1-\mathrm{km}$ buffer to reflect the area that young cavity-nesting owls may use when dispersing from their natal area before independence (Linkhart and Reynolds 2007). The 3-km buffer represented the approximate scale over which owl predators (e.g., Great Horned Owls [Bubo virginianus], Northern Goshawks [Accipiter gentilis], and others; McCallum 1994, Rasmussen et al. 2008) may operate when hunting small owls.

We derived land-cover variables at the $30-\mathrm{m}$ resolution from U.S. Department of Agriculture Forest
Service (USFS) raster layers specific to the BNF, which are extensions of the LANDFIRE Existing Vegetation Type raster dataset. These data were assessed using cross validation techniques and case studies in selected areas. Accuracy assessments ranged between $35-70 \%$ (LANDFIRE 2013).

We defined 11 land-cover classes in the BNF: aspen, barren ground, Douglas-fir, grand fir, lodgepole pine, mixed conifer, non-forest, ponderosa pine, subalpine fir, riparian, and white bark pine (P. albicaulis). Ultimately, our sample size for occurrence prohibited analysis of all 11 land-cover classes individually. Thus, for each of the $0.4-\mathrm{km}, 1-\mathrm{km}$, and 3-km-radius buffers we calculated the proportion of Douglas-fir, ponderosa, and non-forest (i.e., grassland, meadows, sagebrush-steppe, and shrubland land cover) as other researchers have identified these as key habitat-use variables for owls (see McCallum 1994, Christie and van Woudenberg 1997 for Flammulated Owls and Cannings 1987, Rasmussen et al. 2008 for saw-whet owls). We also developed and analyzed a variable that captured land-cover diversity (hereafter diversity) for each of the three spatial scales. To do so, we calculated the Shannon Diversity Index (Shannon and Weaver 1949) based on the number of land-cover classes and the proportion of grid cells in each of those classes. Canopy cover also helps predict Flammulated Owl (McCallum 1994) and saw-whet owl occurrence (Rasmussen et al. 2008, Groce and Morrison 2010). Thus, we used the canopy cover spatial raster data set from the USFS specific to the BNF, which consisted of four categorical raster values $(1=0$ $10 \%$ cover, $2=11-40 \%$ cover, $3=41-70 \%$ cover, and $4=71-100 \%$ cover) at a resolution of $30 \mathrm{~m}$. To reduce number of predictor variables, we reclassified the categorical raster data using midpoints of cover categories (canopy cover category $1=5 \%$ cover, $2=22.5 \%$ cover, $3=55.5 \%$ cover, and $4=$ $85.5 \%$ cover) and then calculated average canopy cover within the $0.4-\mathrm{km}, 1-\mathrm{km}$, and $3-\mathrm{km}$ buffers. We derived the topographic variables aspect and terrain ruggedness index (TRI) from 30-m resolution digital elevation model (The National Map 2013) using ArcMap 9.3. Because aspect had a circular distribution, we calculated the cosine of aspect for each grid cell to constrain values between 1 (more north-facing) and -1 (more south-facing) and modeled aspect as a linear variable. Terrain ruggedness index represented the topographic heterogeneity of an area expressed as the average amount of elevation difference between adjacent 
cells in a digital elevation model (Riley et al. 1999); values of " 0 " represented flat terrain, while values approaching 18 represented extremely rugged terrain. For each of these land cover and topographical variables, we averaged grid-cell values within the 0.4$\mathrm{km}, 1-\mathrm{km}$, and 3-km buffers to model cavity-nesting owl occupancy.

Statistical Analysis. We used PRESENCE 3.1 (USGS Patuxent Wildlife Research Center, Laurel, Maryland, U.S.A.) to estimate occupancy $(\psi)$ and detection $(p)$ probabilities, the influence of land cover and topography covariates on $\psi$, and temporal and environmental covariates on $p$ for Flammulated and saw-whet owls from the owl detection history data (MacKenzie et al. 2002). This modeling framework requires that species are present at occupied sites for the duration of the sampling period (MacKenzie et al. 2002). As Flammulated Owls are obligate migrants that generally return to our study area beginning no earlier than May (Barnes and Belthoff 2008), we used only those surveys conducted during June to model detectability and occupancy of Flammulated Owls.

We used a hierarchical approach (Doherty et al. 2008, Doherty et al. 2010, Aldridge et al. 2012) by first modeling $p$ and $\psi$ separately to develop a base detection model and a candidate set of occupancy models. To model $p$, we tested all variables independently using univariate, single-season occupancy models as well as the null model $(\psi[],. p[]$.$) . We$ carried the most predictive variable(s) based on Akaike's Information Criterion corrected for small sample sizes $\left(\mathrm{AIC}_{c}\right.$; Burnham and Anderson 2002) forward as the base detection model and used it throughout the assessment of the candidate occupancy model set (see Aldridge et al. 2012). We used the land-cover variables Douglas-fir, ponderosa, non-forest, canopy cover, and diversity and the topographic variables aspect and TRI to model $\psi$. We normalized covariates prior to analysis in program PRESENCE, which helped with model convergence. Therefore, we present standardized beta estimates throughout. As we visited different point-count locations in 2009 and 2010, we did not model the effect of year on $\psi$.

No published landscape-scale studies for owl species in Idaho existed with which to base a priori models (Burnham and Anderson 2002); thus, we conducted an exploratory analysis by first identifying the scale (i.e., $0.4-\mathrm{km}, 1-\mathrm{km}$, or $3-\mathrm{km}$ ) that most appropriately described Flammulated Owl and sawwhet owl occupancy for each variable using single- season occupancy models. We considered the most appropriate scale for modeling each variable the one ranked with the lowest $\mathrm{AIC}_{c}$ of the three scales examined. We removed from the set those variables whose $\mathrm{AIC}_{c}$ were greater than the $\mathrm{AIC}_{c}$ of the null model $(\psi[],. p[]$.$) and variables with beta coeffi-$ cients overlapping zero in $75 \%$ confidence intervals (see Doherty et al. 2008). If variables were collinear (Spearman rank correlations $r_{\mathrm{s}} \geq 0.70$ ), we retained the variable we deemed of greater conservation utility in modeling owl occurrence and excluded the other. We ultimately explored owl-habitat association with single-season occupancy estimation using all possible combinations of remaining variables to estimate $\psi$ along with the base detection model for $p$. To avoid over-fitting, we restricted the number of covariates for $\psi$ to approximately $10 \%$ of the sites occupied by each species (Hosmer and Lemeshow 2000).

We used $\mathrm{AIC}_{c}$ and the associated model weights to assess strength of candidate models. When there was model selection uncertainty, we used averaged coefficients from models with a cumulative $\mathrm{AIC}_{c}$ weight of 0.95 (Burnham and Anderson 2002). We recalculated model weights to sum to 1.0 for models in the final candidate set. When model averaging, we set coefficients to zero for variables not included in a model.

Model Diagnostics. In logistic regression, models can be evaluated using a sensitivity/specificity approach, where sensitivity is the ability of a model to correctly classify occupied point-count locations and specificity refers to how well the model classifies unoccupied point-count locations. A point-count location with a predicted probability below a given sensitivity threshold was classified as unoccupied, whereas an observation above this threshold was classified as occupied. We conducted this evaluation over a wide range of sensitivity threshold values to generate receiver operating characteristic (ROC) curves (Fielding and Bell 1997). The ROC curve evaluated the relationship between the number of correctly classified occupied sites and the number of sites classified incorrectly as occupied at different sensitivity thresholds (Pearce and Ferrier 2000).

To assess goodness-of-fit of final models, we calculated the area under the curve (AUC) of the ROC. The AUC is the summed area underneath the ROC curve and provides an index of the model's ability to differentiate between observations of owl occurrence and nonoccurrence. AUC values of 0.5-0.7 reflect relatively poor model performance, 

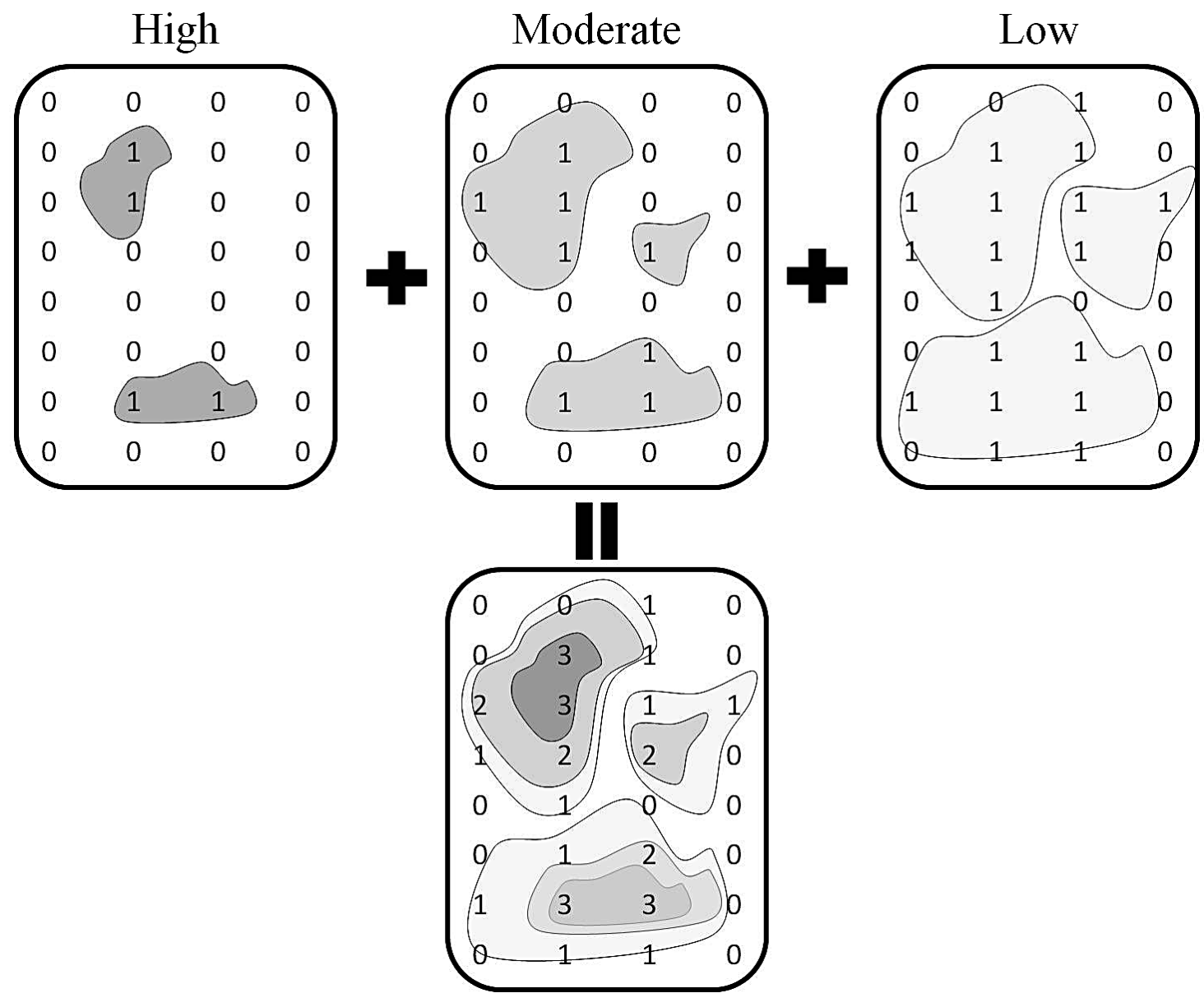

Figure 2. This heuristic illustrates our method used to classify the high, moderate, and low-suitability habitat for Flammulated and Northern Saw-whet owls throughout the Boise National Forest. Occurrence (1) and nonoccurrence (0) locations are based on the three selected sensitivity thresholds where $50 \%, 75 \%$, and $100 \%$ of occupied point-count locations were correctly classified by the model. Summing the three maps results in grid cells where values range between 0-3. Regions with higher values represent high suitability habitat (darker gray areas on map; cell value $=3$ ), and regions with lower values represent areas of least suitability (white areas on map, cell value $=0$ ).

0.7-0.9 moderate performance, and $\geq 0.9$ excellent model performance (Swets 1988).

Habitat Suitability Maps. We applied the modelaveraged final model in ArcMap 9.3 to spatially depict the probability of occupancy separately for Flammulated and saw-whet owls. Species information presented as occurrence/nonoccurrence may be more useful than probability estimates for resource managers (Liu et al. 2005). Therefore, we converted model generated probability estimates into occurrence/nonoccurrence categories using sensitivity thresholds identified by the ROC curve. We generated three maps using sensitivity thresholds where $100 \%, 75 \%$, and $50 \%$ of occupied point count locations were correctly classified. We then summed these maps to create a final composite map, which depicted habitat suitability in four categories: high, moderate, low, and least (Fig. 2).

Model Validation. We assessed accuracy of the final Flammulated Owl model by determining how well it predicted occurrence/nonoccurrence for an independent sample of occupied and unoccupied ( $n=91$ for each) point-count locations in the BNF that were previously surveyed for Flammulated Owls using similar survey techniques to ours (see Barnes 2007). We classified the independent sites as high, moderate, low, or least suitable and assessed the accuracy of occupancy classification using 
Table 1. Model selection for top performing models (10 of 42) examining habitat associations of Flammulated Owls in the Boise National Forest, 2009-2010. Akaike weights have been adjusted to reflect relative weight within the modelaveraged set of 12 models, which accounted for $>0.95$ Akaike weight and were used in calculating model-averaged coefficients for occupancy $(\psi)$, detectability $(p)$, and their associated covariates. Subscripts indicate the most appropriate scale (i.e., $0.4-\mathrm{km}, 1-\mathrm{km}$, or $3-\mathrm{km}$ scale) used to model a variable. The null model is shown below for comparison.

\begin{tabular}{|c|c|c|c|c|}
\hline OCCUPANCY MODEL & $K^{\mathrm{a}}$ & $\mathrm{AIC}_{c} \mathrm{~b}$ & $\Delta \mathrm{AIC}_{c}{ }^{\mathrm{c}}$ & $w_{i}^{\mathrm{d}}$ \\
\hline$\psi\left(\right.$ aspect $_{3 \mathrm{~km}}$, diversity $_{1 \mathrm{~km}}$, Douglas-fir $\left.\mathrm{r}_{0.4 \mathrm{~km}}\right), p$ (noise $)$ & 6 & 152.83 & 0.00 & 0.39 \\
\hline$\psi\left(\right.$ diversity $_{1 \mathrm{~km}}$, Douglas-fir $\left._{0.4 \mathrm{~km}}\right), p($ noise $)$ & 5 & 153.45 & 0.62 & 0.28 \\
\hline$\psi\left(\right.$ canopy $_{0.4 \mathrm{~km}}$, diversity $_{1 \mathrm{~km}}$, Douglas-fir $\left._{0.4 \mathrm{~km}}\right), p$ (noise $)$ & 6 & 155.67 & 2.84 & 0.09 \\
\hline$\psi\left(\right.$ diversity $_{1 \mathrm{~km}}$, Douglas-fir $_{0.4 \mathrm{~km}}$, non-forest $\left.{ }_{1 \mathrm{~km}}\right), p$ (noise) & 6 & 156.06 & 3.23 & 0.08 \\
\hline$\psi\left(\right.$ diversity $_{1 \mathrm{~km}}$, Douglas-fir $_{0.4 \mathrm{~km}}$, ponderosa $\left._{3 \mathrm{~km}}\right), p$ (noise $)$ & 6 & 156.79 & 3.96 & 0.05 \\
\hline$\psi\left(\right.$ aspect $_{3 \mathrm{~km}}$, canopy $_{0.4 \mathrm{~km}}$, diversity $\left._{1 \mathrm{~km}}\right), p$ (noise) & 6 & 157.88 & 5.05 & 0.03 \\
\hline$\psi\left(\right.$ canopy $_{0.4 \mathrm{~km}}$, diversity $\left.1 \mathrm{~km}\right), p$ (noise) & 5 & 158.33 & 5.50 & 0.03 \\
\hline$\psi\left(\right.$ aspect $_{3 \mathrm{~km}}$, diversity $\left._{1 \mathrm{~km}}\right), p$ (noise $)$ & 5 & 158.53 & 5.70 & 0.02 \\
\hline$\psi\left(\right.$ aspect $_{3 \mathrm{~km}}$, Douglas-fir $_{0.4 \mathrm{~km}}$, ponderosa $\left._{3 \mathrm{~km}}\right), p($ noise $)$ & 6 & 159.67 & 6.84 & 0.01 \\
\hline$\psi\left(\right.$ aspect $_{3 \mathrm{~km}}$, diversity $_{1 \mathrm{~km}}$, ponderosa $\left._{3 \mathrm{~km}}\right), p$ (noise $)$ & 6 & 160.94 & 8.11 & 0.01 \\
\hline$\psi(),. p($ noise $)$ & 2 & 176.64 & 23.81 & 0.00 \\
\hline
\end{tabular}

a No. of parameters.

b Akaike Information Criterion corrected for small sample sizes.

c Difference in $\mathrm{AIC}_{c}$ relative to the top model.

d Akaike wt.

contingency analysis conducted in SAS, version 9.2 (SAS Institute, Inc. 2008). We could not evaluate model performance for saw-whet owls because no independent data were available.

\section{RESUlts}

In 2009 and 2010, we conducted 702 visits to 150 point-count locations to examine owl occupancy. We did not detect any Boreal Owls, and detections of Flammulated Owls did not occur until 1 June of each year. We detected saw-whet owls at point-count locations from 15 February to 19 April 2009 and 2010. Detections of saw-whet owls were highest in February of both years (45\% of detections) with successively fewer detections in March (31\%) and April (24\%). Overall, the point-counts produced 42 Flammulated Owl detections and 71 saw-whet owl detections at 27 and 45 locations, respectively. Flammulated and saw-whet owls co-occurred at eight point-count locations, and at least one of the two species was detected at 64 separate point-count locations (43\% of locations).

Variable Selection. Of the temporal and environmental variables we evaluated for association with owl detection, noise accounted for 0.99 and 0.92 of the Akaike weights for Flammulated Owls and saw-whet owls, respectively. Thus, we carried noise forward in the base detection model for both owl species. The scales for Douglas-fir $(0.4 \mathrm{~km})$, non-forest $(1 \mathrm{~km})$, and ponderosa $(3 \mathrm{~km})$ were similar for both species, and scales for the remaining variables differed between species. For Flammulated Owls, canopy was selected for at the $0.4-\mathrm{km}$ scale, diversity at the 1$\mathrm{km}$ scale, and aspect and TRI at the 3-km scale. For saw-whet owls, the most appropriate scale for modeling TRI was the $0.4-\mathrm{km}$ scale; canopy and aspect were selected for at the 1-km scale, and diversity at the 3$\mathrm{km}$ scale. After determining the appropriate scale for each occupancy variable for Flammulated Owls, none of the remaining variables were highly correlated. For saw-whet owls, the variables diversity and ponderosa were correlated $(|r|>0.73)$. We chose to include ponderosa in subsequent modeling because ponderosa pine is a commercially important lumber species and knowledge of its importance to native wildlife is valuable for conservation and management planning in the BNF. For Flammulated Owls, the $75 \%$ confidence intervals for the beta estimates included zero for TRI, so we dismissed TRI from subsequent modeling. No variables at their appropriate scale had $75 \%$ confidence intervals overlapping zero for saw-whet owls.

Model Selection. We developed a set of 42 occupancy models for Flammulated Owls using all possible combinations of the six remaining variables and the base detection model. Similarly, we developed a set of 63 models for saw-whet owls. From the candidate models, 12 models for Flammulated Owls (Table 1) and 25 
Table 2. Model selection for top performing models (10 of 63) examining habitat associations of Northern Saw-whet Owls in the Boise National Forest, 2009-10. Akaike weights have been adjusted to reflect relative weight within the modelaveraged set of 25 models, which accounted for $>0.95$ Akaike weight. Subscripts indicate the most appropriate scale (i.e., 0.4-km, 1-km, or 3-km scale) used to model a variable. The null model is shown below for comparison.

\begin{tabular}{|c|c|c|c|c|}
\hline OCCUPANCY MOdEL & $K^{\mathrm{a}}$ & $\mathrm{AIC}_{c}^{\mathrm{b}}$ & $\Delta \mathrm{AIC}_{c}{ }^{\mathrm{c}}$ & $w_{i}^{\mathrm{d}}$ \\
\hline $\begin{array}{l}\psi\left(\text { aspect }_{1 \mathrm{~km}}, \text { Douglas-fir }\right. \\
0.4 \mathrm{~km}\end{array}$ & 8 & 332.54 & 0.00 & 0.14 \\
\hline$\psi\left(\right.$ aspect $_{1 \mathrm{~km}}$, Douglas-fir $_{0.4 \mathrm{~km}}$, non-forest ${ }_{1 \mathrm{~km}}$, ponderosa $\left._{3 \mathrm{~km}}\right), p$ (noise $)$ & 7 & 332.65 & 0.11 & 0.13 \\
\hline$\psi\left(\right.$ aspect $_{1 \mathrm{~km}}$, Douglas-fir ${ }_{0.4 \mathrm{~km}}$, non-forest $\left.{ }_{1 \mathrm{~km}}, \mathrm{TRI}_{0.4 \mathrm{~km}}\right), p$ (noise) & 7 & 333.46 & 0.92 & 0.09 \\
\hline$\psi\left(\right.$ aspect $_{1 \mathrm{~km}}$, non-forest $_{1 \mathrm{~km}}$, ponderosa $\left._{3 \mathrm{~km}}\right), p$ (noise $)$ & 6 & 333.81 & 1.27 & 0.08 \\
\hline$\psi\left(\right.$ aspect $_{1 \mathrm{~km}}$, non-forest $\left._{1 \mathrm{~km}}, \mathrm{TRI}_{0.4 \mathrm{~km}}\right), p($ noise $)$ & 6 & 334.07 & 1.53 & 0.07 \\
\hline$\psi\left(\right.$ aspect $_{1 \mathrm{~km}}$, non-forest $_{1 \mathrm{~km}}$, ponderosa $\left._{3 \mathrm{~km}}, \mathrm{TRI}_{0.4 \mathrm{~km}}\right), p$ (noise $)$ & 7 & 334.26 & 1.72 & 0.06 \\
\hline$\psi\left(\right.$ Douglas-fir $_{0.4 \mathrm{~km}}$, non-forest ${ }_{1 \mathrm{~km}}$, ponderosa $\left._{3 \mathrm{~km}}, \mathrm{TRI}_{0.4 \mathrm{~km}}\right), p$ (noise $)$ & 7 & 334.48 & 1.94 & 0.05 \\
\hline $\begin{array}{l}\psi\left(\text { aspect }_{1 \mathrm{~km}}, \text { canopy }_{1 \mathrm{~km}}, \text { Douglas-fir }_{0.4 \mathrm{~km}}, \text { non-forest }_{1 \mathrm{~km}}, \text { ponderosa }_{3 \mathrm{~km}}\right) \text {, } \\
p \text { (noise })\end{array}$ & 8 & 335.08 & 2.54 & 0.04 \\
\hline$\psi\left(\right.$ aspect $_{1 \mathrm{~km}}$, canopy $_{1 \mathrm{~km}}$, Douglas-fir $_{0.4 \mathrm{~km}}$, non-forest $\left._{1 \mathrm{~km}}, \mathrm{TRI}_{0.4 \mathrm{~km}}\right), p$ (noise) & 8 & 335.13 & 2.59 & 0.04 \\
\hline$\psi\left(\right.$ aspect $_{1 \mathrm{~km}}$, non-forest $\left._{1 \mathrm{~km}}\right), p($ noise $)$ & 5 & 335.55 & 3.01 & 0.03 \\
\hline$\psi(),$.$p (noise)$ & 2 & 348.90 & 16.36 & 0.00 \\
\hline
\end{tabular}

a No. of parameters.

b Akaike Information Criterion corrected for small sample sizes.

c Difference in $\mathrm{AIC}_{c}$ relative to the top model.

d Akaike wt.

e Terrain ruggedness index derived from a digital elevation model.

models for saw-whet owls (Table 2) were included for model averaging. Relative importance $\left(w_{+}\right)$values suggested that Flammulated Owls occurred in landscapes with low land cover diversity and a high proportion of Douglas-fir forest (Table 3). The importance of aspect was moderate, but canopy, non-forest, and ponderosa were poorly supported (Table 3).

There was also lack of support for any one sawwhet owl model (Table 2) as top approximating models had low Akaike weights $(w<0.15)$ and small differences between $\mathrm{AIC}_{c}$ values $\left(\Delta \mathrm{AIC}_{c}<\right.$ 2.0). The variables non-forest and aspect stood out as most important (Table 3) and indicated that sawwhet owl occupancy increased with southern-facing aspects and in areas with higher proportions of nonforest. The remaining five variables received low to moderate support, with $w_{+}$ranging from 0.22 (canopy) to 0.63 (ponderosa; Table 3 ).

Probability of Detection and Occupancy. Mean probability of detection adjusted for ambient noise was high for Flammulated and saw-whet owls ( $p=$ $0.93 \pm 0.05$ and $0.77 \pm 0.08 \mathrm{SE}$, respectively). Noise had a negative effect on detectability for both Flammulated Owls (odds ratio $=0.18,95 \%$ CI $=0.09-$ 0.42 ) and saw-whet owls (odds ratio $=0.34,95 \% \mathrm{CI}=$ $0.20-0.58)$, and neither species of owl was detected where noise index was four. Flammulated Owls had a model-averaged probability of site occupancy $(\psi)$ of $0.22 \pm 0.03 \mathrm{SE}$, while saw-whet owls were more likely to occur $(\psi=0.40 \pm 0.01 \mathrm{SE})$.

Spatial Implementation in GIS. For Flammulated Owls, we applied the final model-averaged logistic regression equation

$$
\begin{gathered}
\text { Occupancy }=1.286-2.544(\text { aspect })+0.064(\text { canopy }) \\
-1.209(\text { diversity })+0.994(\text { Douglas }- \text { fir }) \\
-0.021 \text { (non-forest })+0.013(\text { ponderosa })
\end{gathered}
$$

in a GIS. Similarly, we implemented the final modelaveraged results for saw-whet owls using the logistic regression equation

$$
\begin{aligned}
& \text { Occupancy }=-0.387-0.495(\text { aspect })-0.048(\text { canopy }) \\
& +0.273(\text { Douglas-fir })+0.915(\text { non-forest }) \\
& +0.323(\text { ponderosa })-0.268(\text { TRI })
\end{aligned}
$$

Spatial projections of relative habitat suitability showed the potential for Flammulated and saw-whet owls to occupy a large proportion of the BNF (Fig. 3a, b). For Flammulated Owls, the spatial projection of habitat suitability (Fig. 3a) contained large areas of both highly suitable $\left(2744 \mathrm{~km}^{2}\right)$ and least suitable $\left(4553 \mathrm{~km}^{2}\right)$ habitat, with smaller 

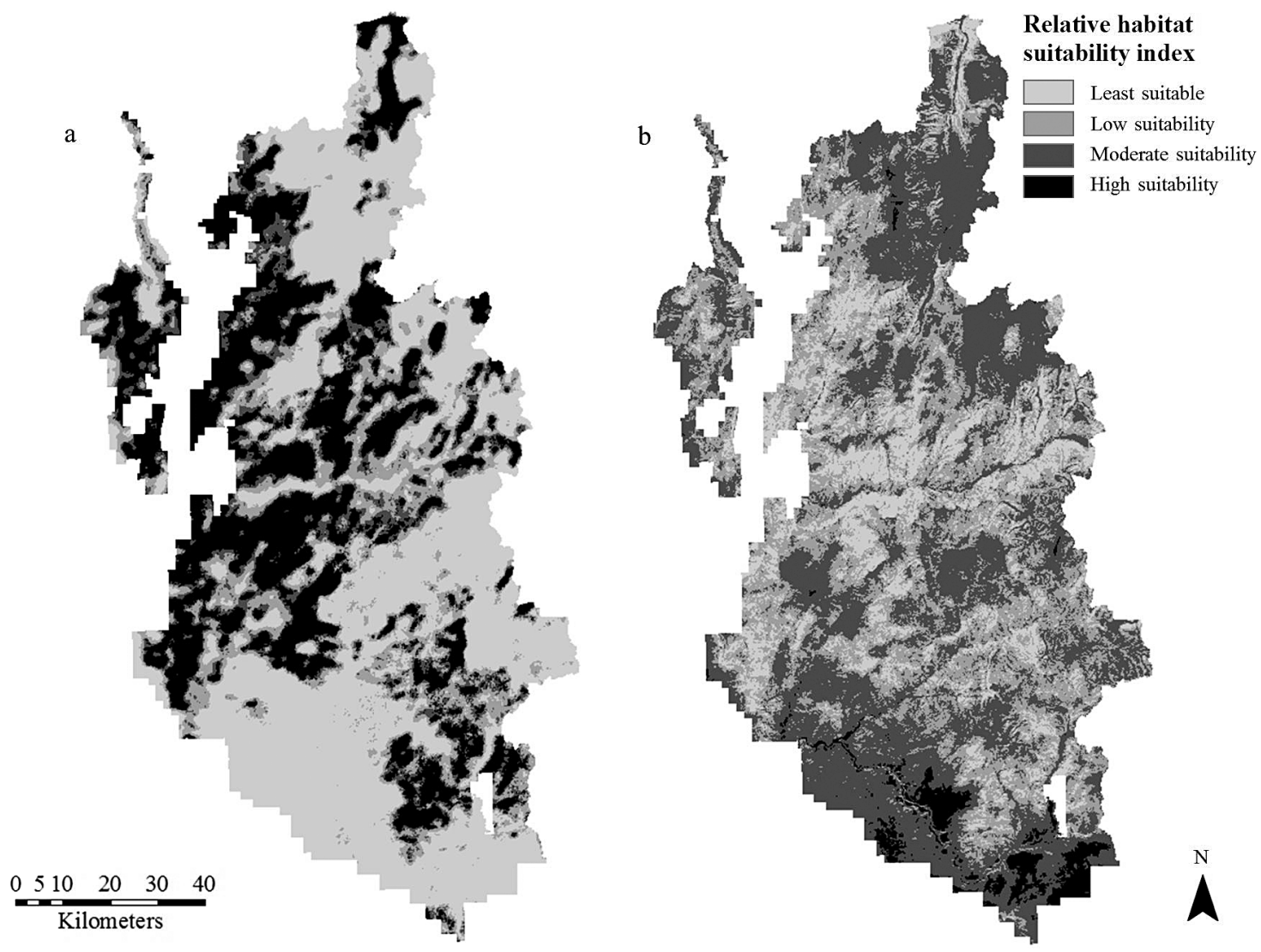

Figure 3. Habitat suitability maps based on cumulative spatial projections of 50, 75, and $100 \%$ of correctly classified occupied sites for (a) Flammulated Owls and (b) Northern Saw-whet Owls in the Boise National Forest, Idaho, U.S.A. based on data collected during 2009-2010.

Table 3. Relative importance $\left(w_{+}\right)$of individual variables and model averaged standardized coefficients $(\beta) \pm$ standard errors associated with each variable in the $95 \%$ confidence set for Flammulated Owls $(n=27)$ and Northern Saw-whet Owls $(n=45)$ in the Boise National Forest, 2009-2010. Relative importance was calculated by summing the cumulative Akaike weights across the total number of models $(\mathrm{N})$ in which a particular variable occurred. $*=$ variable eliminated during the variable reduction procedure.

\begin{tabular}{|c|c|c|c|c|c|c|c|}
\hline \multicolumn{4}{|c|}{ FLAMMULATED OWLS } & \multicolumn{4}{|c|}{ NORTHERN SAW-WHET OWLS } \\
\hline VARIABLE & $\mathrm{N}$ & $w_{+}$ & $\beta$ & VARIABLE & $\mathrm{N}$ & $w_{+}$ & $\beta$ \\
\hline Diversity $_{1 \mathrm{~km}}$ & 10 & 0.98 & $-1.209 \pm 0.447$ & Non-forest $1 \mathrm{~km}$ & 25 & 1.00 & $0.915 \pm 0.345$ \\
\hline Douglas-fir $_{0.4 \mathrm{~km}}$ & 7 & 0.91 & $0.994 \pm 0.378$ & Aspect $_{1 \mathrm{~km}}$ & 15 & 0.80 & $-0.495 \pm 0.248$ \\
\hline Aspect $_{3 \mathrm{~km}}$ & 6 & 0.46 & $-2.544 \pm 2.636$ & Douglas-fir $_{0.4 \mathrm{~km}}$ & 13 & 0.63 & $0.273 \pm 0.181$ \\
\hline Ponderosa $3 \mathrm{~km}$ & 4 & 0.08 & $0.013 \pm 0.043$ & Ponderosa $_{3 \mathrm{~km}}$ & 13 & 0.63 & $0.323 \pm 0.215$ \\
\hline Non-forest $t_{1 \mathrm{~km}}$ & 2 & 0.08 & $-0.021 \pm 0.031$ & $\mathrm{TRI}_{0.4 \mathrm{~km}}$ & 14 & 0.57 & $-0.268 \pm 0.188$ \\
\hline Canopy $_{0.4 \mathrm{~km}}$ & 3 & 0.06 & $0.065 \pm 0.073$ & Canopy $_{1 \mathrm{~km}}$ & 11 & 0.22 & $-0.048 \pm 0.700$ \\
\hline TRI & $*$ & $*$ & $*$ & Diversity & $*$ & $*$ & $*$ \\
\hline
\end{tabular}


amounts of moderate $\left(1192 \mathrm{~km}^{2}\right)$ and low $\left(1771 \mathrm{~km}^{2}\right)$ suitability habitat. The spatial projection for saw-whet owls (Fig. 3b) differed in that the majority of the BNF was predicted to be of moderate $\left(4557 \mathrm{~km}^{2}\right)$ or low $\left(3836 \mathrm{~km}^{2}\right)$ suitability, and smaller areas were of least $\left(1569 \mathrm{~km}^{2}\right)$ and highly $\left(298 \mathrm{~km}^{2}\right)$ suitable habitat.

Model Performance. The ability of the final models to distinguish between occupied and unoccupied sites was moderate for both species. The AUC was 0.71 for Flammualted Owls and 0.70 for sawwhet owls. For one to correctly identify $100 \%$ of the occurrence observations, $77 \%$ and $83 \%$ of nonoccurrence sites would be incorrectly classified for Flammulated Owls and saw-whet owls, respectively. For both owl species, the overall percentage of correctly classified occupied and unoccupied point-count locations was highest when we applied models using a sensitivity of $50 \%$. At this level, occupied and unoccupied sites were correctly classified for $70 \%$ and $69 \%$ of the point-count locations we surveyed for Flammulated Owls and saw-whet owls, respectively.

When compared against the independent sample of 182 Flammulated Owl point-count locations from Barnes (2007), there was a significant association between those occupied sites and areas on the map categorized as high to moderate suitability $\left(\chi^{2}=26.03\right.$, df $\left.=3, p=<0.001\right)$. Of the occupied point-count locations, $58 \%$ were in areas that our final model classified as having the highest suitability. Moreover, no occupied sites from Barnes' (2007) study occurred in areas that the final predictive model classified as least suitable habitat.

\section{DISCUSSION}

Applying habitat models in GIS has become a common approach to project the probability of species occurrence across large spatial scales. We explored the influence of land cover and topographic variables on the occupancy of Flammulated Owls and saw-whet owls in a national forest in Idaho, and determined spatial scales at which these variables were associated with owl occupancy. The most appropriate scale describing owl occurrence was similar for Douglas-fir, non-forest, and ponderosa, whereas scale for canopy cover, aspect, TRI, and diversity differed between owl species. This highlights the importance of allowing scale to vary by species. Understanding the scale of habitat association is important because (1) we often know little about the scale at which a species responds to characteristics of its environment, and (2) different species may respond to their environments in different ways. Additionally, our study of owl occupancy incorporated multiple visits to each point-count location, which allowed us to establish and incorporate detection probabilities. These procedures improve inferences for species such as nocturnal forest owls that are likely to be imperfectly detected (Bailey et al. 2009, Yakulic et al. in press).

Probability of Detecting Cavity-nesting Owls. Like Barnes and Belthoff (2008), we found that the probability of detecting Flammulated Owls was high $(p=0.93)$ during June, which was after owls returned from migration and the month during which our surveys for this species were focused. Saw-whet owls also had a relatively high detection probability $(p=0.77)$, and detections were most common during February point-counts. Groce and Morrison (2010) reported much lower detection probabilities $(p=0.28 \pm 0.04 \mathrm{SE})$ for saw-whet owls in the Lake Tahoe Basin, California, and Nevada. However, their observations were from midMarch through June when owls may have been somewhat less responsive to conspecific calls (Rasmussen et al. 2008).

We found that detectability of both owl species decreased when noise index levels exceeded two (some intermittent, but not distracting noise). Kissling et al. (2010) reported effects of noise on detectability of saw-whet owls in southeastern Alaska, where noise levels $\geq 3$ (moderate noise that could reduce owl detectability) reduced detection probabilities by about two-thirds. Higher noise levels could have reduced our ability to detect owls, or it may have altered their responses to broadcasted vocalizations. Recent studies indicate that anthropogenic noise clearly affects bird distributions (McClure et al. 2013). Thus, it is also possible that noise affected owl occupancy, such as if owls avoided areas where noise was prominent. In our study, higher noise was frequently associated with point-count locations near rivers and larger streams that swelled with spring runoff rather than with anthropogenic noise. Barnes (2007) hypothesized that Flammulated Owls avoided areas with larger-order streams or rivers where noise levels are high because the owls use hearing to detect predators in social interactions and when foraging.

Habitat Associations of Flammulated Owls. The habitat suitability model we derived for Flammulated 
Owls successfully distinguished between occupancy in highly suitable and least suitable habitat. Although some previous researchers have found that Flammulated Owls are predominately associated with ponderosa pine (Bull et al. 1990, Linkhart et al. 1998), Flammulated Owls can occur in a variety of forest types including aspen, lodgepole pine, subalpine fir, and Douglas-fir (McCallum 1994, Powers et al. 1996, Marti 1997). Ponderosa pine was not a strong predictor of Flammulated Owl occupancy in our study. However, there was a strong positive relationship between the proportion of Douglas-fir and Flammulated Owl occurrence. In addition to ours, other studies have found that Flammulated Owls tend to occur in areas with a high proportion of Douglas-fir (Howie and Ritchey 1987, Powers et al. 1996, Christie and van Woudenberg 1997). Mature stands of Douglasfir forest may present the favorable park-like stands and open forest physiognomy of primary importance to these owls (McCallum 1994, Linkhart et al. 1998).

Land-cover diversity at the $1-\mathrm{km}$ scale had a strong negative relationship with owl occurrence. Diversity was a derived variable from 11 land cover classes of which nine were forested and two were non-forested classes (i.e., non-forest and barren ground). Low diversity may be a result of either (1) homogeneous forest landscapes dominated by a few forested land-cover classes around a pointcount location, or (2) heterogeneous landscapes consisting of many land cover classes in small patches. Most sites that Flammulated Owls occupied consisted primarily of Douglas-fir, ponderosa pine, or a combination of these two land-cover classes. Lower occupancy in high diversity landscapes could therefore be a reflection of Flammulated Owls using relatively contiguous tracts of forest consisting of only a few cover classes. Given that Douglas-fir at the $0.4-\mathrm{km}$ scale was an important predictor of Flammulated Owl occupancy, Flammulated Owls may be likely to occupy patches of Douglas-fir $(0.4 \mathrm{~km}$ scale) surrounded by a matrix of relatively homogeneous cover types more likely to be forest than non-forest.

Although model-averaged estimates of aspect from our study were only moderately supported, the observed relationships were in agreement with Bull et al. (1990) and Barnes (2007), who found that Flammulated Owls were more likely to occupy east-facing and south-facing slopes. South-facing aspects in colder regions of Idaho and Oregon may experience earlier release of snow pack thereby creating favorable conditions for arthropod prey, which Flammulated Owls require. The physiological demands of thermoregulation may also restrict these small owls to areas that experience warmer temperatures early in the breeding season when the greatest cold stress occurs (McCallum 1994).

Our final habitat model indicated a lack of support for the land-cover variable non-forest. The scale of our landscape-level approach may have been too coarse to detect the effects of non-forest if it occurred at finer scales. This seems possible, as Barnes (2007) found that Flammulated Owls frequently foraged in small $(<0.5 \mathrm{ha})$, open clearings within the BNF. Likewise, Bull et al. (1990) reported that more than half of known Flammulated Owl nest trees located in northeastern Oregon occurred within $30 \mathrm{~m}$ of a 1-ha opening.

Canopy cover as we measured it from raster data specific to the BNF also was not a strong predictor of Flammulated Owl occurrence. In contrast, Flammulated Owl use of intermediate levels of canopy cover has been well documented (Bull et al. 1990, Moore and Fredrick 1991, Barnes 2007). Several of these researchers observed that a multilayered structural component of canopy cover was important (Bull et al. 1990, Moore and Fredrick 1991), which is something our landscape-level approach did not address.

Habitat Associations of Saw-whet Owls. The final predictive habitat model for saw-whet owls performed moderately well and indicated that the majority of the BNF is of moderate suitability for this species. Model-averaged results indicated non-forest at the 1-km scale had a strong positive influence on saw-whet owl occupancy. Saw-whet owls frequently hunt in forest openings, along forest edges (Hayward and Garton 1988), and in sagebrush and bitterbrush shrubland (Cannings 1987). Therefore, a higher proportion of non-forested grassland and shrubland within $1 \mathrm{~km}$ of occupied point-count locations may represent areas of suitable foraging habitat.

As was the case with Flammulated Owls, aspect was important in explaining saw-whet owl occupancy, and model coefficients indicated that saw-whet owl occupancy increased with increasing south-facing aspects at the $1-\mathrm{km}$ scale. Land with a southfacing slope within the study area may warm more quickly. Because of their small size, saw-whet owls may seek thermoregulatory benefits from warmer temperatures on south-facing slopes when they 
arrive to establish territories in February and March. During April and May, these areas may warm faster than north-facing aspects, which likely provides greater access to microtine rodents at a time when owls are brooding and rearing young (Cannings 1987).

Saw-whet owl occupancy was positively related to both proportion of ponderosa land cover at the 3$\mathrm{km}$ scale and to Douglas-fir land cover at the $1-\mathrm{km}$ scale. In the western United States, saw-whet owls occupy a variety of conifer forests with ponderosa pine, Douglas-fir, grand fir, western larch (Larix occidentalis), and western red cedar (Thuja plicata) supporting the densest populations of birds (Hayward and Garton 1988, Rasmussen et al. 2008). Thus, saw-whet owls are typically more general in their habitat use than many other forest-dwelling owl species. Grossman et al. (2008) found that saw-whet owls occupied a variety of landscapes with the amount of forested area ranging from 16-100\% within $0.8 \mathrm{~km}$-radius plots. The positive relationship between saw-whet owls and ponderosa pine and Douglas-fir in our study may also reflect the relatively higher abundance of these two forest types in the BNF.

Terrain ruggedness (TRI) had a negative influence on saw-whet owl occupancy, so owls were more likely to occur in areas with little topographic relief. Saw-whet owls may occupy rugged areas less if foraging conditions are suboptimal. Saw-whet owls hunt from low perches on branches or shrubs, often in forest openings or near forest edges (Rasmussen et al. 2008). There may have been a lack of such hunting perches or adequate cover needed by sawwhet owls when foraging in areas with high values for TRI. Alternatively, owls may have used rugged areas less if preferred prey were lacking there.

Finally, we found that saw-whet owl occupancy had a weak but negative relationship with canopy cover, which also may have been related to the importance of non-forested areas for foraging. Likewise, Groce and Morrison (2010) found that open canopy was influential for saw-whet owl occupancy in California and Nevada. However, they noted that scale is important in that open canopy was more relevant at the scale of saw-whet owl territories (e.g., 20-ha plots) rather than larger scales (e.g., 1$\mathrm{km}$ radius) such as those we found to be important.

Management Implications. Our results from southern Idaho indicate that detection of saw-whet owls was greatest in February, while Flammulated Owls were not detected until June. Although ambient noise strongly influenced the probability of detecting both owl species, we do not recommend that such highnoise areas be avoided during surveying. Rather, we suggest models depicting the occupancy of either species should incorporate variables such as a noise index or other environmental covariates to account for imperfect detection, as others suggest (Kissling et al. 2010). Establishing multiple visits to each survey point will further help to increase the probability of detecting these owls and therefore increase the reliability of occupancy estimates (MacKenzie et al. 2002).

The Flammulated Owl and saw-whet owl models we developed identified occupancy variables at scales greater than the approximate sizes of home ranges for both species as being important predictors of owl occurrence. This suggests that habitat for Flammulated Owls and saw-whet owls needs to be managed at scales beyond their home range. Currently, there are several efforts underway to return forest composition within the BNF and similar western forests to a state more closely resembling that of pre-European settlement (Idaho Department of Fish and Game 2005). From a management perspective, generating multiple habitat suitability maps allows land managers flexibility in how they allocate management resources across larger landscapes. If it is not possible to focus on all suitable owl habitat, then protection or restoration efforts can concentrate only on habitat predicted to be most suitable (i.e., $50 \%$ sensitivity). Conversely, if the goal is to conserve habitat for these owl species in all regions where they are likely to occur, then a scenario using a $100 \%$ sensitivity map can be used to guide management efforts. Therefore, the spatially explicit models we developed for Flammulated and sawwhet owl occupancy can provide land managers with a practical tool with which to identify highly suitable land cover and to help inform land-use decisions or restoration efforts. Although we developed these models specifically for use in the BNF, we suspect that their applicability extends to areas where similar habitat types occur throughout the western United States.

\section{ACKNOWLEDGMENTS}

We thank R. Miller, I. Seferovich, A. Sherwood, and L. Vanderlugt for their assistance in data collection and L. Nutt (USDA Forest Service, Boise National Forest) for logistical support, help with project planning, and project funding. Project funding was also provided by the Department of Biological Sciences and the Raptor Research Center at Boise State University. L. Bond and S. Hanser provided very helpful input on statistical analyses. The manuscript was greatly improved by comments from $\mathrm{J}$. 
Heath, A. McCallum, R. Gutiérrez, S. Lewis, J. Brown, and two anonymous reviewers.

\section{Literature Cited}

Aldridge, C.L., D.J. Saher, T.M. Childers, K.E. StahlNECKER, AND Z.H. BowEN. 2012. Crucial nesting habitat for the Gunnison Sage-grouse: a spatially explicit hierarchical approach. Journal of Wildlife Management 76:391-406.

Bailey, L.L., J.A. Reid, E.D. Forsman, And J.D. Nichols. 2009. Modeling co-occurrence of Northern Spotted and Barred owls: accounting for detection probability difference. Biological Conservation 142:2983-2899.

BARNES, K.P. 2007. Ecology, habitat use, and probability of detection of Flammulated Owls in the Boise National Forest. M.S. thesis, Boise State University, Boise, ID U.S.A.

— AND J.R. BeLthoff. 2008. Probability of detection of Flammulated Owls using nocturnal broadcast surveys. Journal of Field Ornithology 79:321-328.

Bull, E.L., A.L. Wright, AND M.G. Henjum. 1990. Nesting habitat of Flammulated Owls in Oregon. Journal of Raptor Research 24:52-55.

Burnham, K.P. AND D.R. ANDERSON. 2002. Model selection and inference: a practical information-theoretic approach, Second Ed. Springer-Verlag, New York, NY U.S.A.

CAnnings, R.J. 1987. The breeding biology of Northern Saw-whet Owls in southern British Columbia. Pages 191-198 in R.W. Nero, R.J. Clark, R.J. Knapton, and R.H. Hamre [EDS.], Biology and conservation of northern forest owls. U.S.D.A. Forest Service Gen. Tech. Rep. RM-142, Rocky Mountain Forest and Range Experiment Station, Fort Collins, CO U.S.A.

Christie, D.A. AND A.M. van Woudenberg. 1997. Modeling critical habitat for Flammulated Owls (Otus flammeolus). Pages 97-106 in J.R. Duncan, D.H. Johnson, and T.H. Nicholls [EDS.], Biology and conservation of owls of the northern hemisphere. U.S.D.A. Forest Service Gen. Tech. Rep. NC-190, North Central Forest Experiment Station, St. Paul, MN U.S.A.

Cushman, S.A. AND K. McGarigal. 2002. Hierarchical, multiscale decomposition of species-environmental relationships. Landscape Ecology 17:637-646.

Doherty, K.E., D.E. NAugle, And B.L. WAlker. 2010. Greater Sage-grouse nesting habitat: the importance of managing at multiple scales. Journal of Wildlife Management 72:187-195.

- - , - AND J.M. Graham. 2008. Greater Sage-grouse winter habitat selection and energy development. Journal of Wildlife Management 72:187-195.

Fielding, A.H. AND J.F. BELL. 1997. A review of methods for the assessment of prediction errors in conservation presence/absence models. Environmental Conservation 24:38-49.

Francis, C.M. AND M.S.W. Bradstreet. 1997. Monitoring boreal forest owls in Ontario using tape playback surveys with volunteers. Pages 175-184 in J.R. Duncan,
D.H. Johnson, and T.H. Nicholls [EDS.], Biology and conservation of owls of the northern hemisphere. U.S.D.A. Forest Service Gen. Tech. Rep. NC-190, North Central Forest Experiment Station, St. Paul, MN U.S.A.

Fuller, M.R. AND J.A. Mosher. 1987. Raptor survey techniques. Pages 37-66 in B.A. Giron Pendleton, B.A. Millsap, K.W. Cline, and D.M. Bird [EDs.], Raptor management techniques manual. National Wildlife Federation, Washington, DC U.S.A.

Groce, J.E. AND M.L. Morrison. 2010. Habitat use by sawwhet owls in the Sierra Nevada. Journal of Wildlife Management 74:1523-1532.

Grossman, S.R., S.J. Hannon, and A. Sanchez-Azofeifa. 2008. Responses of Great Horned Owls (Bubo virginianus), Barred Owls (Strix varia), and Northern Saw-whet Owls (Aegolius acadicus) to forest cover and configuration in an agricultural landscape in Alberta, Canada. Canadian Journal of Zoology 86:1165-1172.

Hayward, G.D. AND E.O. GaRTON. 1988. Resource partitioning among forest owls in the River of No Return Wilderness, Idaho. Oecologia 75:253-265.

Hosmer, D.W. And S. Lemeshow. 2000. Applied logistic regression. John Wiley and Sons, New York, NY U.S.A.

Howie, R.R. AND R. Ritchey. 1987. Distribution, habitat selection, and densities of Flammulated Owls in British Columbia. Pages 249-254 in R.W. Nero, R.J. Clark, R.J. Knapton, and R.H. Hamre [EDS.], Biology and conservation of northern forest owls. U.S.D.A. Forest Service Gen. Tech. Rep. RM-142, Rocky Mountain Forest and Range Experiment Station, Fort Collins, CO U.S.A.

IDAHO DEPARTMENT OF FISH AND GAME. 2005. Idaho comprehensive wildlife conservation strategy. Idaho Conservation Data Center, Idaho Department of Fish and Game, Boise, ID U.S.A. http:/ fishandgame.idaho.gov/cms/ tech/CDC/cwcs.cfm (last accessed 15 June 2012).

Imbeau, L.M. Mönkkönen, And A. Desrochers. 2001. Long-term effects of forestry on birds of the eastern Canadian boreal forests: a comparison with Fenonoscandia. Conservation Biology 15:1151-1162.

Johnson, R.R., B.T. Brown, L.T. Haight, And J.M. SimPSON. 1981. Playback recordings as a special avian censusing technique. Studies in Avian Biology 6:68-75.

Kissling, L.M., S.B. Lewis, And G. Pendleton. 2010. Factors influencing the detectability of forest owls in southeastern Alaska. Condor 112:539-548.

LANDFIRE. 2013. LANDFIRE project. U.S.D.A. Forest Service, U.S.A. www.landfire.gov/dp_quality_assessment. php (last accessed 15 November 2013).

LINKHART, B.D. AND R.T. REYNOLDS. 2007. Return rate, fidelity, and dispersal in a breeding population of Flammulated Owls (Otus flammelous). Auk 124:246-275.

- - — AND R.A. RyDER. 1998. Home range and habitat of breeding Flammulated Owls in Colorado. Wilson Bulletin 110:342-351.

Liu, C., P.M. Brerry, T.P. Dawson, and R.G. Pearson. 2005. Selecting thresholds of occurrence in the prediction of species distributions. Ecography 28:385-393. 
MacKenzie, D.I., J.D. Nichols, G.B. Lachman, S. Droege, J.A. Royle, And C.A. Langtimm. 2002. Estimating site occupancy rates when detection probabilities are less than one. Ecology 83:2248-2255.

Marti, C.D. 1997. Flammulated Owls (Otus flammeolus) breeding in deciduous forests. Pages 262-266 in J.R. Duncan, D.H. Johnson, and T.H. Nicholls [EDS.], Biology and conservation of owls of the northern hemisphere. U.S.D.A. Forest Service Gen. Tech. Rep. NC190, North Central Forest Experiment Station, St. Paul, MN U.S.A.

McCallum, D.A. 1994. Flammulated Owl (Otus flammeolus). In A. Poole [ED.], The birds of North America online, No. 93. Cornell Lab of Ornithology, Ithaca, NY U.S.A. http://bna.birds.cornell.edu/bna/species/ 093 (last accessed 15 September 2009).

McClure, C.J.W., H.E. Ware, J. Carlisle, G. Kaltenecker, AND J.R. BARBER. 2013. An experimental investigation into the effects of traffic noise on the distributions of birds: avoiding the phantom road. Proceedings of the Royal Society B 280:1-9.

MoOre, T.L. AND G.D. Fredrick. 1991. Distribution and habitat of Flammulated Owls (Otus flammeolus) in west-central Idaho. Idaho Department of Fish and Game, Boise, ID U.S.A.

Pearce, J. and S. Ferrier. 2000. Evaluating the predictive performance of habitat models developed using logistic regression. Ecological Modeling 133:225-245.

Powers, L.R., A. Dale, P.A. Gaede, C. Rodes, L. Nelson, J.J. Dean, And J.D. May. 1996. Nesting and food habits of the Flammulated Owl (Otus flammeolus) in south central Idaho. Journal of Raptor Research 30:15-20.

Rasmussen, J.L., S.G. Sealy, and R.J. Cannings. 2008. Northern Saw-whet Owl (Aegolius acadicus). In A. Poole [ED.], The birds of North America online, No. 42. Cornell Lab of Ornithology, Ithaca, NY U.S.A. http://bna. birds.cornell.edu/bna/species/042 (last accessed 10 September 2009).
Riley, S.J., S.D. Degloria, AND R. Elliot. 1999. A terrain ruggedness index that quantifies topographic heterogeneity. Intermountain Journal of Science 5:23-27.

Russell, R.E., V.A. SAab, AND J.G. Dudley. 2007. Habitatsuitability models for cavity-nesting birds in a postfire landscape. Journal of Wildlife Management 71:2600-2611.

SAAB, V.A., R.E. Russell, AND J.G. DudLEy. 2007. Nest densities of cavity-nesting birds in relations to postfire salvage logging and time since wildfire. Condor 109: 97-108.

Shannon, C.E. And W. Weaver. 1949. The mathematical theory of communication. University of Illinois Press, Urbana, IL U.S.A.

Steele, R., R.D. Pfister, R.A. Ryker, and J.A. Kittams. 1981. Forest habitat types of central Idaho. U.S.D.A. Forest Service Gen. Tech. Rep. INT-114, Intermountain Research Station, Ogden, UT U.S.A

SwETS, J.A. 1988. Measuring the accuracy of a diagnostic system. Science 240:1285-1293.

The National Map. 2013. The national map viewer. U.S.D.I. Geological Survey, U.S.A. www.nationalmap. gov/viewer.html (last accessed 31 December 2010).

Turner, M.G., R.H. Gardner, and R.V. O’NeIll. 2001. Landscape ecology in theory and practice: pattern and process. Springer-Verlag, New York, NY U.S.A.

Wisdom, M.J., R.S. Holthausen, B.C. Wales, C.D. Hargis, V.A. SAAB, D.C. LEe, W.J. HanN, T.D. Rich, M.M. RowLAND, W.J. MuRPHY, AND M.R. EAMEs. 2000. Source habitats for terrestrial vertebrates of focus in the interior Columbia basin: broad-scale trends and management implications. U.S.D.A. Forest Service Gen. Tech. Rep. GTR-485, Pacific Northwest Research Station, Portland, OR U.S.A.

Yakulic, B.C., J.A. ReID, J.D. Nichols, J.E. Hines, R. DaVis, AND E.D. Forsman. In press. The roles of competition and habitat in the dynamics of populations and species distributions. Ecology http:/ /dx.doi.org/10.1890/13-0012.1.

Received 17 July 2013; accepted 2 January 2014 Associate Editor: Jessi L. Brown 